\title{
Democracy Compromised: A Study of Adiga's The White Tiger
}

\author{
Dr. Pralayankar Kumar Singh
}

Lecturer in English

Government Polytechnic

Asthawan, Nalanda

Bihar, India

pralayankar.singh.kumar@gmail.com

\section{Abstract}

The paper tries to underscore that how one of the oldest democracies of the world is exposed to corruption. Corruption has brought India not only to halt but also dragging it backward. Corruption in India stems from the connection between bureaucrats, politicians and criminals. Adiga writes that there are mainly three diseases in India typhoid, cholera and election fever of which election is the worst. Election is the very fountainhead of all types of corruption. Voters casting their votes for money or even for a bottle of liquor are a common practice in many cities of India. Politicians before election make many promises but once government is formed they forget the promises. Balram Halwai, the protagonist, owes his success to the bribe that he gave to political institutions. In corruption police stands second to none. Taking hefty amount of bribe, they protect the big-wigs from legal proceedings. They harass and arrest mostly the have-nots and the honest. The police are totally rotten in Delhi, the capital of India. "If they see you without a seat belt, you'll have to bribe them a hundred rupees", says Balram. The police appointed with a view to control crime and maintain law and order promotes crime by taking bribe. Corruption in education system has crippled the poor. The 
mid-day meal of the students is taken home by the teacher of the school. Balram's school teacher sells the uniform of the students in the neighbouring villages to earn profit. He is carried to the hospital, where no doctor is present saved a ward boy. The ward boy tells Balram that the doctor might come in the evening only when Balram gives him ten rupees bribe. Balram asks a person who is beside him "why isn't a doctor here uncle". The man answers that the doctor gives a fat amount of bribe to higher officials to get that job and after getting the job the bribes government medical superintendent one third of their salary to mark their attendance. The corruption in health department costs the life of Balram's father. Blaram's father has been suffering from tuberculosis. He is carried to the hospital, where no doctor is present saved a ward boy. The ward boy tells Balram that the doctor might come in the evening only when Balram gives him ten rupees bribe. Balram asks a person who is beside him "why isn't a doctor here uncle". The man answers that the doctor gives a fat amount of bribe to higher officials to get that job and after getting the job the bribes government medical superintendent one third of their salary to mark their attendance. People lose their confidence in their politicians and civil servants. The largest democracy of the world is being compromised.

Keywords:- Democracy, Corruption, Bribe, Education, Health, Unemployment, Exploitation

"The tale of how I was corrupted from a sweet, innocent village fool into a citified fellow full of debauchery, depravity, and wickedness" (Adiga 197).

Democracy is said to be the best form of governance. It is a form of government in which the ultimate power is vested in the citizens and is exercised by them directly or indirectly through a system of representation usually involving periodic free elections. Democracy is run by the elected representatives of the people. A genuine democracy should 
have a Constitution that vests ultimate power in people and protects citizens' fundamental rightsviz., equality, liberty of thought and expression, belief, movement, communication and association. It should empower citizens with franchise for electing representatives. It should have a responsible government in which the executive should be answerable to the legislature and the legislature to the people. The democratic system must ensure social status, social security and social welfare. It should facilitate a situation where the fruits of economic development may reach all especially the have not's and deprived section of the society.

Although Indian democracy has been celebrated all around the globe for its working yet it has many drawbacks. Corruption is one of them. Corruption is the abuse of power for private gains against the public good. Corruption Perception index shows that the continued failure of most countries to significantly control corruption chips away at democracy to produce a vicious cycle, where corruption undermines democratic institutions and, in turn, weak institutions are less able to control corruption" (https//www.transparency.org./news). Corruption in India stems from the connection between bureaucrats, politicians and criminals. In The White Tiger Aravind Adiga underscores the rampant corruption which has brought India not only to halt but also dragging it backward. In the novel Balram Halwai through a series of letters addressed to Wen Jiabao, the Chinese Premier, narrates the story of his success as an entrepreneur. In his narration he exposes how government institutions are over head and ears in corruption. Corruption has been taken for granted as being the way things are and always will be.

In The White Tiger, Adiga writes that there are three main diseases in India "typhoid, cholera and election fever. The last one is the worst." (Adiga 98). Elections which bring a promise of democratic accountability- allowing the voters to spurn those politicians who fail to deliver good performance and choose those they believe will work for society.Thecondition of voters in Laxmangarh is very pitiable. They discuss the election 
helplessly like "eunuchs discussing the Kama Sutra." (98). A very astonishing fact of Indiandemocracy is revealed when Balram says, "I am India's most faithful voter and I still have not seen the inside of the voting booth" (102). This flaunts the rampant corruption in policies and abuse of power. Voters casting their votes for money or even for a bottle of liquor are a common practice in many cities of India. Balram gives a vivid description of election in Laxmangarh:

I had to be eighteen. All of us in tea shop had to be eighteen, the legal age to vote. There was an election coming up, and the tea shop owner had already sold us. He had sold our fingerprints- the inky fingerprints which the illiterate person makes on the ballot paper to indicate his vote... he had got a good price for each one of us from the Great socialist's party(97).

It is said that election is the very fountainhead of all types of corruption. When a person is paid for voting either a person or a party without exercising a political consensus, it is allowing the funding person or the party influencing not only the election but also the rest of the five years reign. In one way or the other each policy will be carefully knit as per the needs of the funding person or the party. Election Commission of India publicizes election as a "joyous festival of democracy". But this five-yearly mass participation exercise has caused such a dismal foreboding.Corrupt electorate will elect corrupt politicians.

Politicians before election make many promises but once government is formed they forget the promises. In Laxmangarh, there were three different foundation stones for a hospital laid by three different politicians before three different elections" (47). Medical services have been made an object of political opportunism. The great socialist established Lohia Universal Free Hospital in view of election result. But doctors hardly visit the hospital. The rooms of hospitals are also not hygienic and lack basic amenities. Balram describes the hospital: 
Cat has tasted blood. A couple of Muslim men had spread a newspaper on the ground and were sitting on it. One of them had an open wound on his leg. He invited us to sit with him and his friend. Kishan and I lowered the father onto the newspapers sheets. We waited there...the Muslim men kept adding newspapers to the ground, and the line of diseased eyes, raw wounds, and delirious mouths kept growing (48-49).

The great Socialist, whom people believed their messiah, sells the vacant post of the physicians in the local government hospital for 'four hundred thousand rupees. He does not care if the doctor is at all attending the poor patients in the hospital or not' (29). In India corrupt politicians go scot-free and unharmed because they are either big-wigs in politics or close to the centre of power. People rarely feel shocked when politicians' corrupt practices are divulged. The irony of Indian society is that such people are honoured and treated as savior of the poor.

Corruption has created a division within the society over shadowing all others. In the olden days, Adiga writes, there were one thousand castes and destinies in India. But now there exists only two casts "Men with Big Bellies and Men with Small Bellies. And only two destinies: eat- or get eaten up"(64). In such conditions only the strongest man can survive and enjoy every privilege. The people who cannot give a befitting reply like Balram's father have to fall all the way to the mud, to the level of rickshaw-puller. His body epitomizes his sufferings.

A rich man's body is like a premium cotton pillow, white and soft and blank. Ours are different. My father's spine was a knotted rope, the kind that women use in villages, to pull water from wells; the clavicle curved around his neck in high relief, like a dog's collar; cuts and nicks and scars, like little whip marks in his flesh, ran down his chest and waist, reaching down below his hip bones into his buttocks. The story of a poor man's life is written on his body, in a sharp pen (27). 
In India most of the people for employment are directly or indirectly dependent on agriculture. A large section of agricultural land is owned by a handful of people called Zamindars. Though Zamindari Pratha has been abrogated, it's still one of the most powerful media of exploitation of the have-nots especially in villages. In the village of Laxmangarh there are four zamindars named The Buffalo, Stork, Wild Boar and Raven. Their names reflect their characteristics. The Stork is the owner of the river that flows outside the Laxmangarh, and "he took a cut of every catch of fish caught by every fisherman in the river, and a toll from every boatman who crossed the river" (24) to reach the village. All the good agricultural land belongs to the wild Boar. Men who wanted to work on those lands- had to bow down to his feet, and touch the dust under his slippers, and agree to sallow his day wages.” (24)

The piece of land which was dry, rocky hillside around the fort was owned by the Raven. He "took a cut from goatherds who went up there to graze with their flocks. If they didn't have their money, he liked to dip his beak into their backsides" (25). The Buffalo was the greediest of the lot. He had "eaten up the rickshaws and the roads. So if you ran a rickshaw, or used the road, you had to pay him his feed- one third of whatever you earned, no less" (25). Their greed makes Adiga call them "Animals". Balram had to drop his school to work at a tea shop because his family had borrowed money from The Stork. When his family fails to pay the debt, they become bonded labour under the Stork.

There is a huge gulf between the urban people and rural people and this is ever widening too. Over the last twenty or thirty years urban areas have been doing exceptionally well in generating opportunity and employment. There the income and the living standard of the people have improved substantially,whereas in the rural areas the opportunity and employment have reached its nadir. In the rural areas the dropped income of the people has 
exposed them to maltreatment and exploitation. This has brought substantial changes in their living standard and morale.

In corruption police stands second to none. Taking hefty amount of bribe, they protect the big-wigs from legal proceedings. They harass and arrest mostly the have-nots and the honest. The hit and run case which legally belongs to Pinky Madam is shifted to Balram. This is the lot of the servants in India that they are framed for the murder committed on the road. They are forced to sign the confession by the police.Judiciary too joins hands in this crime. The judges overlook the forced out confession because they are in the racket too. They take bribe. They ignore the discrepancies in the case. And life goes on." (170).

Balram owes his success to the bribe that he gave to political institutions. He knows well that he lives in a country where money and power matters. Moral values and traditional ideologies are a matter of speech before the people. When he establishes himself as Ashok Sharma, an entrepreneur in Bangalore, he asserts that he is "one of those who cannot be caught in India" (320) because has enough money to silence the people. In fact, he has killed his owner Ashok and later adopts his name. A village fool, Balram Halwai, become Ashok Sharma, a wily entrepreneur. He in me because they happened first in Mr. Ashok. He returned from America an innocent man but life in Delhi corrupted him- and once the master of Honda city becomes corrupted, how can the driver stay innocent?" (197).

After murdering his owner Balram is a fugitive. Despite being one of the most wanted men, he casts his votes in every election, be it local, state or general without going inside the booth. Actually somebody else casts his vote. So what Adiga wants to hint here is that fake voting is very common during Indianelection "The elections? All wrapped up. It's a landslide. Minister said so this morning. Elections, my friend, can be managed in India; it's not like America" (212) 
Delhi is not a city for the honest. The police are very corrupt. Balram mentions "The main thing to know about Delhi is that the roads are good, and the people are bad. The police are totally rotten. If they see you without a seat belt, you'll have to bribe them a hundred rupees" (124). The police appointed with a view to control crime and maintain law and order promotes crime by taking bribe.

Corruption in education system has crippled the poor. In the village of Laxmangarh Balram's school teacher has not received salary for nearly six months. So he teaches nothing to the students until the paycheck arrives. The mid-day meal of the students is taken home by the teacher of the school. He justifies it saying 'he hadn't been paid his salary in six months' (33). The mid-day meal was started by the governments of different states of India in primary and upper primary schools realizing the fact that a child who is either hungry or ill can't learn. Under this scheme children are given free lunches on working days. Mid-day meal effectively works in improving the nutritional status of children in classes I to VIII in government local Body and Government aided schools and EGS (Education Guarantee Scheme and AIE (Alternate Innovative Education) centres. The Central Government supplies food free of cost for the scheme. For its successful implementation in remote areas Panchayats and Nagarpalikas are also involved. The total charges for cooking, supervision and kitchen are eligible for assistance under Poverty Alleviation Programme. The mid-day meal encourages the poor children from the deprived section to attend school more regularly and helps them perform class room activity regularly. Moreover it reduces the number of dropouts.

Balram's school teacher sells the uniform of the students in the neighbouring villages to earn profit. Ensuring education to all, the Government provides students uniform. It is distributed among all boys and girls students from class $\mathrm{I}$ to $\mathrm{X}$ in Government and Government aided schools. It is one of the initiatives taken to provide free and compulsory 
education to all children. It aims at retaining the enrolled students at the school until compulsory stage. School uniform stops students competing in their attire and more attention is given to studies. It reduces economic inequality and inculcates a feeling of community among the students. These corrupt practices of the teachers creep in the mind of the students. This proves the training of corruption to the future of India.

Blaram's father has been suffering from tuberculosis. He is carried to the hospital, where no doctor is present saved a ward boy. The ward boy tells Balram that the doctor might come in the evening only when Balram gives him ten rupees bribe. Balram asks a person who is beside him "why isn't a doctor here uncle". The man answers that the doctor gives a fat amount of bribe to higher officials to get that job and after getting the job the bribes government medical superintendent one third of their salary tomark their attendance. The corruption in health department costs the life of Balram's father.

The Indian elite, whose members have had disproportionate access to education, resources and opportunities has allowed all these malpractices continue unchecked. Surging corruption leads to a declining trust in elites and the state. People lose their confidence in their politicians and civil servants. The largest democracy of the world is being compromised. To ensure proper functioning of democracy, India will have to work on its loopholes. To ensure proper functioning of democracy India will have to strengthen institutions and preserve checks and balances, fill the implemental gap between anti-corruption legislation, practices and enforcement. It will have to empower its citizens to express themselves. The citizens must be encouraged to vote for the right candidate. It should work assiduously to eradicate poverty. It should guarantee fundamental education to all. It must also ensure impartial and responsible media. 


\section{References}

Adiga, Aravind. The White Tiger. Noida: Harper Cosllins Publishers, 2008.

https//www.transparency.org./new 